\title{
COMPARATIVE ANALYSIS OF ACTIVE AND PASSIVE RECREATIONAL CONSUMPTION HABITS OF DISABLED CHILDREN LIVING IN THE NORTHERN GREAT PLAIN REGION
}

\author{
Authors: \\ Nóra Laoues-Czimbalmos \\ University of Debrecen (Hungary) \\ Anetta Müller (PhD.) \\ University of Debrecen (Hungary) \\ Éva Bácsné Bába (PhD.) \\ University of Debrecen (Hungary) \\ E-mail adress of the first author: \\ laoues.nora@ped.unideb.hu
}

Reviewers:

Krisztina Dajnoki (PhD.)

University of Debrecen (Hungary)

György Szabados (PhD.)

University of Debrecen (Hungary)

Laoues-Czimbalmos N., Müller A., \& Bácsné Bába É. (2019): Comparative analysis of active and passive recreational consumption habits of disabled children living in the Northern Great Plain region. Különleges Bánásmód, 5. (1). 31-39. DOI 10.18458/KB.2019.1.31

\begin{abstract}
In our research, we studied the leisure habits of students with disabilities (8-18 years, $n=289)$ living in the North Great Plain region using a questionnaire method. The aim of the research was to examine the leisure habits of children with disabilities in the region, their main characteristics and their recreational attitudes. Our goal was also the gender test to see whether there was a significant difference between the sexes and how this correlated with the results of the study of leisure habits in the wild. We sought to find out what the most common leisure time activities for general and high school students with disabilities are, how does this affect genders? What is their attitude towards spending time on leisure? What are their sporting habits and sporting consumption? We have found that recreational consumption of young people with disabilities is similar to the results of surveys carried among normal children as passive leisure time is dominant (listening to music, watching TV). In girls' leisure time, the preference for listening and reading is more dominant while watching TV, especially popular sports channels, is more characteristic of boys. For leisure-time activities, staying fit, trying out new things, and community experience is crucial for young people with disabilities. Recreational sports prove to be popular, as more than $50 \%$ of both girls and boys say they are engaged in recreational sports.
\end{abstract}

Keywords: disabled students, leisure consumption, sports, attitudes

Disciplines: economics, sociology, special education

\begin{abstract}
Absztrakt
AZ ÉSZAK- ALFÖLDI RÉGIÓBAN ÉLŐ FOGYATÉKOS GYEREKEK AKTÍV ÉS PASSZÍV REKREÁCIÓS FOGYASZTÁSI SZOKÁSAINAK ÖSSZEHASONLÍTÓ ELEMZÉSE

A kutatásunkban az észak-alföldi régióban élő fogyatékos tanulók (8-18 év, $n=283$ ) szabadidős fogyasztási szokásait vizsgáltuk kérdőíves módszerrel. A kutatás során célunk volt megvizsgálni a régióban élô fogyatékos gyerekek szabadidős fogyasztási szokásait, annak főbb jellemzőit, a szabadidős attitúdjüket. Célunk volt a gender vizsgálat is, hogy a nemek tekintetében tapasztalunk-e szignifikáns eltérést és ez az eredmény hogyan viszonyul az épek körében végzett szabadidőfogyasztási szokások vizsgálati eredményeihez. Választ kerestünk arra, hogy mik a fogyatékossággal élő általános és középiskolás tanulók leggyakoribb szabadidő tevékenységei, ez hogyan alakul a nemek viszonylatában? Mi jellemzi a szabadidő eltöltéshez kapcsolódó attitűdjüket? Mi jellemzi a sportolási szokásaikat, sportfogyasztásukat? Megállapítottuk, hogy a fogyatékosággal élő fiatalok szabadidôs fogyasztása hasonlóan alakul, mint azt az épek körében végzett vizsgálatok eredményei is mutatnak, azaz a passzív szabadidő-eltöltés dominál (zenehallgatás, tv nézés). A lányok szabadidôs fogyasztásában a zenehallgatás és olvasás preferenciája
\end{abstract}


dominánsabban jelenik meg, míg a TV-nézésben a sportcsatorna népszerúsége a fiúk körében nagyobb, mint a lányokéban. A szabadidős tevékenységek esetében a fittnek maradni, az új dolgok kipróbálása, a közösségi élmény meghatározó a fogyatékossággal élő fiatalok esetében. A szabadidősport népszerủnek bizonyul, hiszen mind a lányok, mind a fiúk több mint 50\%-a nyilatkozta, hogy végez szabadidős sportot.

Kulcsszavak: fogyatékos diákok, szabadidős fogyasztás, sportolás, attitűd

Diszciplina: gazdaságtudomány, szociológia, gyógypedagógia

According to a survey conducted by the WHO and the World Bank (2011) there are more and more people living with disabilities. The proportion of people with disabilities is on the rise accounting for $15 \%$ of the world's population today. According to the Central Statistical Office (2014), the number of persons with disabilities in Hungary was 577 thousand in 2001, representing $5.7 \%$ of the country's population, however, some estimates suggest that their number could be one million in Hungary. The right of people with disabilities appeared in the 1998 Equal Opportunities Act, and then in 1999 in the Disability Program regulations concerning leisure and sport were issued. The issue of disability had appeared earlier in sports sciences, utilizing the preventive, recreational and rehabilitative effects of sport and its social integration function. Recreational activities, including sports, received special attention in the social integration of persons with disabilities, in exercising their human rights in their therapeutic treatment or even in improving their quality of life.

\section{LITERATURE REVIEW}

Recreation is the culture of spending leisure time, including leisure activities, whether they are mental or physical activities. Its meaning embraces notions such as regeneration, recovery or reintegration. It means the reproduction or extended reproduction of energies of a person tired of work (Dobozy \& Jakabházy, 1992, Kovács, 2003). Its purpose is threefold, as both its relaxing and developmental role can be observed (Borbély and Müller, 2008), supplemented nowdays with its entertainment function (Révész et al., 2015).

In leisure activities, trends in the field of sport and fitness demonstrate that the entertainment and experiential functions are increasingly important motivations in consumer habits (Müller, 2009a, Müller et al., 2017). The role of leisure and recreational activities is gaining increasing attention, as many Hungarian (Michalko, 2012, Mosonyi et al.,
2013, Boda et al., 2015) and international (Dobay, Bánhidi \& Simonek, 2018) scholars place these themes in the focus of their research.

Leisure activities are playing an increasingly important role in tourism, as guests need the development of recreational offerings, making it a factor of competitiveness. The role and importance of leisure supply in tourism are also being studied by several Hungarian (Borbély \& Müller, 2015, Bánhidi, 2016) and international (Shaww \& Coles, 2004, Bullock, Mahon and Killingsworth, 2010) researchers. A health tourism research (Müller et al., 2018) reports that asthmatic patients on a 3week rehabilitation also require and use different leisure-time offerings during their treatment (tours, other sports programs, massages, wellness) aimed at improving their condition and health, that is, their quality of life.

In Hidvégi and Honfi's (2008) research, it is stated that although recreation would be of great importance to persons with disabilities as it could improve their quality of life and condition, they have few opportunities to use it in Hungary. Leisure and recreation have been shown to contribute to the mental and physical health of non-disabled and disabled people (Coleman \& Iso-Ahola, 1993; Coyle et al., 1991; Roberts et al., 1989, Schreyer, 1984).

Nowadays, numerous researches underline that various recreational activities can be used for therapeutic purposes proving that patients' condition and quality of life are improved after the therapeutic use of the different recreational programs (Bedini, 2000; Hodges, Luken \& Zook, 2001; Broach \& Dattilo, 2003; Funderburk \& Callis, 2010; Iwasaki, Coyle \& Shank, 2010; McCornic, Snethen \& Smith, 2012; Lawson, Foster \& Harrington, 2014; Gaskell \& Janssen, 2014; Davis \& Nelson 2015; Alysha, Walter \& Bryan, 2017). Several international studies have examined the national economic aspects of the physical activity of persons with disabilities (Johnson, 2009), the factors supporting and inhibiting physical activity (Block, Taliaferro \& Moran, 2013), the role of in- 
clusive sport for mentally disabled in their socialization (Bota, Teodorescu \& Serbanoiu, 2014), physical activity, lifestyle and daily life of disabled people, (Kisow, 2015) or the labour market opportunities of people with disabilities (Balázs-Földi \& Dajnoki, 2016; Móré \& Mező, 2016).

The importance of regular sports for people with disabilities, among the leisure activities, is emphasized by several authors (Sáringerné, 2014; Gombás, 2016; Laoues, 2017), as they can help them improve their condition and quality of life, socialization and gaining of community experiences.

\section{METHOD}

The research was carried out in the three counties of the Northern Great Plain Region (HajdúBihar, Jász-Nagykun-Szolnok and SzabolcsSzatmár-Bereg), among the students who participate in special and integrated education. respondents' study at institutions of primary and secondary education. An online questionnaire was applied in the research. The questionnaires were completed by 283 students. The students completed the questionnaires with the help and guidance of interviewers (teachers). The aim of the research was to examine the recreational habits of children with disabilities living in the region, the main characteristics of these habits and their leisure attitudes. In addition, our goal was to examine whether there is a significant difference between the sexes and how our results compare to the results of research leisure habits of normal children.

In our research we were looking for the answer to the following questions: What are the most common leisure activities of primary and secondary school students with disabilities and are there any gender differences? What characterizes their leisure time attitude? What characterizes their sports habits and sports consumption?

Before the research, we assumed that passive (TV, listening to music) and active (sports) recreational activities are dominant in leisure consumption. We also assumed that sports and active leisure are more popular among boys with disabilities than among girls.

\section{Sample}

In the questionnaire respondents were asked to specify what type of disability they had. 50.9\% of the respondents had some disability in learning, $26.7 \%$ were mentally handicapped and 9\% were physically disabled. The pupils of disabilities participated in the research in almost the same proportion: Pupils with other psychiatric disorders accounted for $4.1 \%$, visually impaired 3.7\%, pupils with impaired hearing $3.4 \%$ and pupils with speech disabilities $2.2 \%$. The disability-specific distribution of respondents is shown in Figure 1.

Figure 1.: Disability-specific distribution of respondents (Source: Authors' editing)

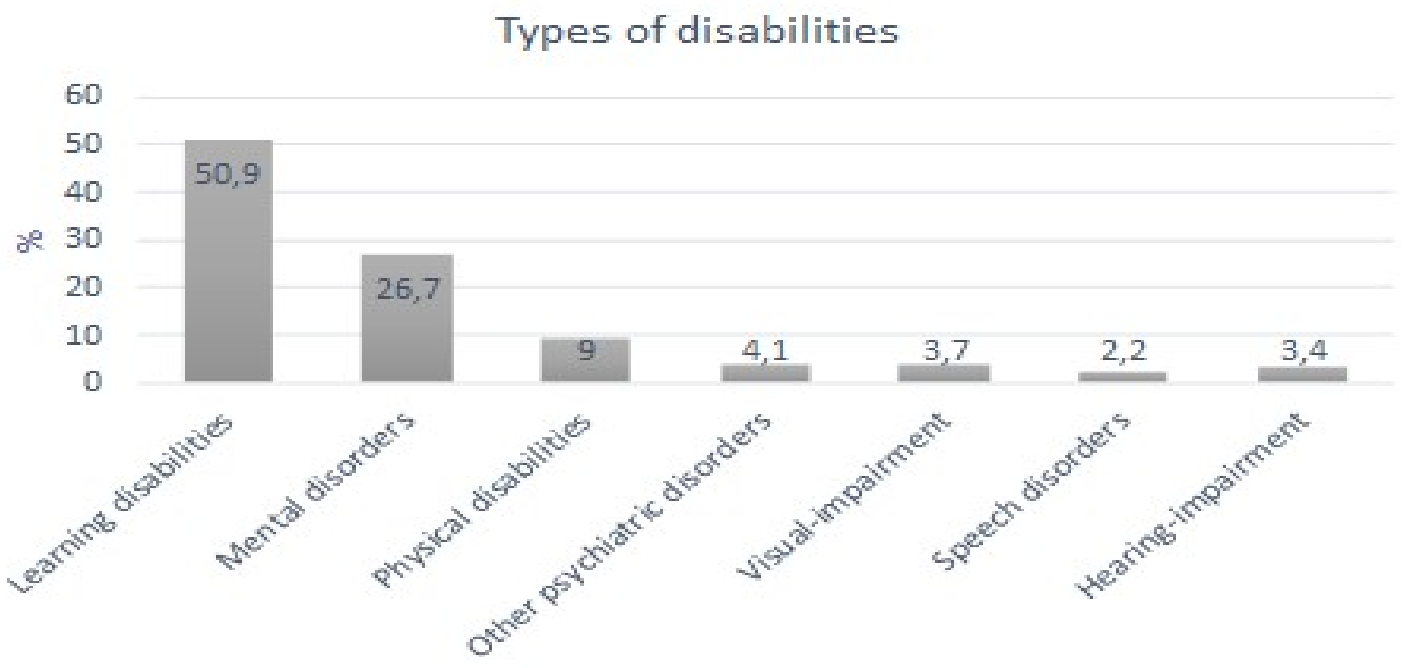


Distribution of respondents by school type

$54 \%(\mathrm{n}=153)$ of students participating in the research were upper graders, $39.2 \%(\mathrm{n}=111)$ of high school students, $6.8 \%(\mathrm{n}=19)$ of them lowergraders. Figure 2 . shows the number and percentage of elementary and secondary school students participating in the measurement.

\section{Distribution of sample by county:}

$38.9 \%$ of the respondents are from Hajdú-Bihar county, 33.8\% live in Szabolcs-Szatmár-Bereg county and 27.3\% in Jász-Nagykun Szolnok county (see Figure 3).

\section{Settlement type distribution by gender}

A higher proportion, $50.9 \%$, of the surveyed students are urban residents, of which boys account for $58.9 \%$ and girls $41.7 \%$. This is followed by $38.1 \%$ of respondents living in a village, $35.1 \%$ of them being boys and $41.7 \%$ girls., $11 \%$ live in a county seats, $6 \%$ of whom are boys and $16.7 \%$ girls. Figure 4 shows the distribution of settlement type by gender.

Figure 2.: Distribution of respondents by school type (Source: Authors' editing)

Measured students by school type

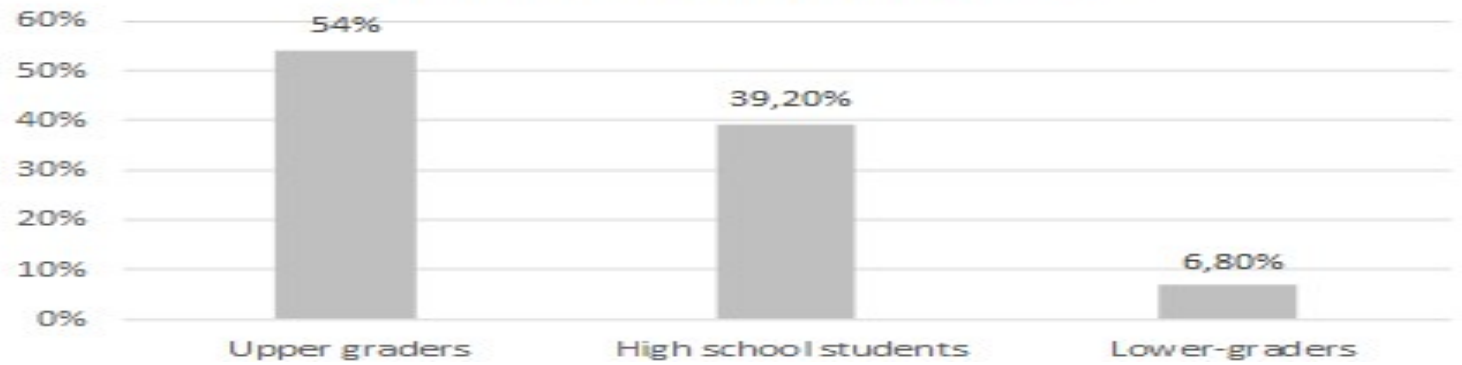

Figure 3.: Distribution of respondents by county (Source: Authors' editing)

\section{Distribution of respondents by county}

50

40

30

20

10

0

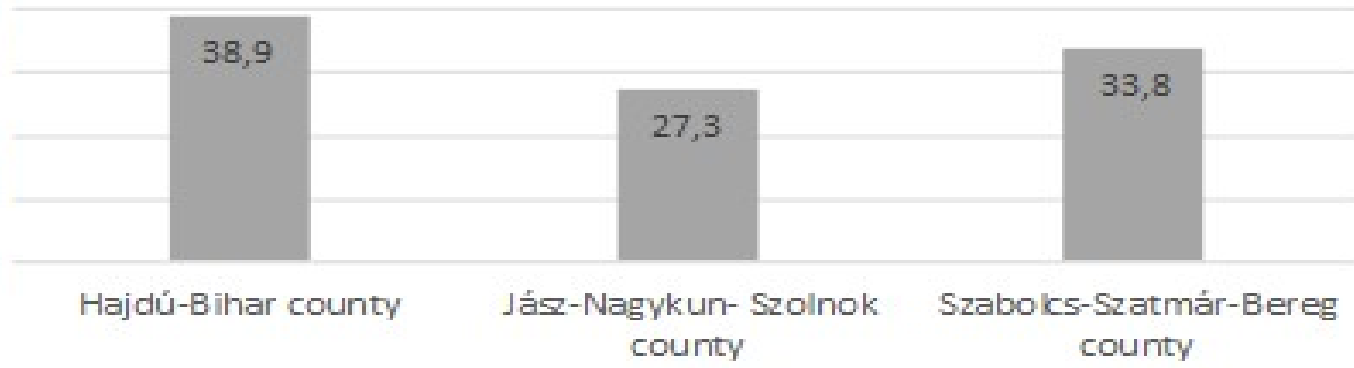

Figure 4.: Settlement type distribution by gender. (Source: Authors' editing)

Town types

70

60

50

40

30

20

10
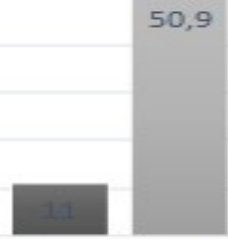

Total

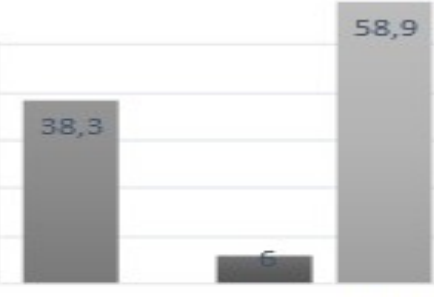

boy

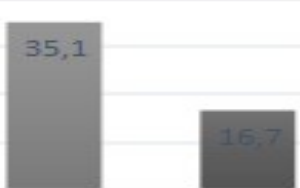

- county seat = urban residents =village
41,7

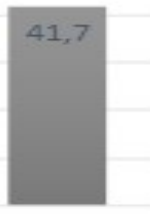




\section{Methods}

Data collection took place in June 2018. The questionnaires were completed anonymously, participation in data collection was voluntary. After data retrieval, results were analysed with the SPSS statistical program. In addition to the basic statistics $\mathrm{Khi}^{2}$ test was employed to test the relationships. The respondents studied in institutions of primary and secondary education, girls accounting for 46.5\%, 132 people and boys for 53.5\%, 151 people in the sample $(n=283)$.

\section{Results}

\section{Habits of spending leisure time}

The percentage breakdown of leisure time habits of the interviewed students by gender is shown in Table 1.

In most of the students' leisure activities listening to music is the most frequent $(71.6 \%)$. In the sample $(\mathrm{n}=283)$ there is a significant difference (Ch2 $=20,666, \mathrm{df}=1, \mathrm{p}=0.000), 84.7 \%$ of girls had chosen listening to music as a leisure activity, while only $60.3 \%$ of boys had chosen it as a recreational activity. In addition to listening to music, TV viewing was also identified as an important intellectual leisure activity, with $52.8 \%$ of the respondents choosing it. In the case of television, there was no significant difference by gender, this is only a tendency (girls $49.6 \%$, boys $55.6 \%$ ). TV watching habits of the surveyed students revealed that there was a significant difference between the genders in watching the sports channel. The consumption of sports channels is more typical for boys $(17.9 \%)$ than for girls $(3.1 \%)$. In terms of reading activity of young people, a significant difference $(\mathrm{Ch} 2=$ $14,871, \mathrm{df}=1, \mathrm{p}=0.000$ ) was found by gender. Girls tend to read more in their leisure time $(26.7 \%)$ than boys $(9.3 \%)$.

The least preferred activities in the leisure time were learning (13.1\%), board games (13.5\%), and competitive sports, however, we could not show a statistically verifiable difference by gender. Our gender-based comparison confirmed the tendency that girls prefer listening to music and reading in their leisure time. As for watching TV, the popularity of the sports channel among boys is greater than among girls. If we look at research done among normal children, in many cases similar results are found in the field of leisure consumption.

Murányi's (2010) recreational research among normal young people $(N=1570)$ concludes that young people prefer individual and passive activities in their leisure time: they mostly use the Internet, listen to music, watch television or videos (DVD) These findings are supported by Szabó (2006) who found that for young people in Budapest the most frequent leisure activity was listening to music, reading newspapers and watching TV. Leisure habits amongst normal youth are similar to the leisure-time results of the disabled youngsters in our research.

In the case of the normal students, Müller's (2009b) research showed different results. She examined 260 college sports majors' leisure time activities and found that career orientation highly influenced the results as $65.6 \%$ of the students (172 people) do sport in their leisure time and 59, $2 \%$ (155 persons) attends a sports event as a spectator (passively) or as an athlete (actively).

However, in addition to an active lifestyle, leisure activities typical for "relaxation" can be observed in their case as well, for example $58.4 \%$ of the students also marked "TV, DVD, watching movies" as a frequent leisure activity. Szabó (2006) showed a difference in the preference system of normal women and men: men prefer to be engaged with computer, sports and sporting events, while women prefer cultural programs such as going to classical music concerts, the cinema and the theatre.

Table 1.: Leisure time spending habits of respondents by (Source: Authors' editing)

\begin{tabular}{|l|l|l|l|l|l|}
\hline Leisure time spending habits & Boy yes & Girl yes & Boy no & Girl no & $\begin{array}{l}\mathrm{p} \text { based on } \\
\mathrm{Ch}^{2} \text { test }\end{array}$ \\
\hline TV & $84(55,6 \%)$ & $56(49,6 \%)$ & $67(44,4 \%)$ & $66(50,4 \%)$ &, 313 \\
\hline Competitive sport & $22(14,6 \%)$ & $12(9,2 \%)$ & $129(85,4 \%)$ & $119(90,8 \%)$ &, 164 \\
\hline Reading & $14(9,3 \%)$ & $35(26,7 \%)$ & $137(90,7 \%)$ & $96(73,3 \%)$ &, 000 \\
\hline Listening to music & $91(60,3 \%)$ & $111(84,7 \%)$ & $60(39,7 \%)$ & $20(15,3 \%)$ &, 000 \\
\hline Watching sport channel & $27(17,9 \%)$ & $4(3,1 \%)$ & $124(82,1 \%)$ & $127(96,9 \%)$ &, 000 \\
\hline Board games & $21(13,9 \%)$ & $17(13,1 \%)$ & $130(86,1 \%)$ & $113(86,9 \%)$ &, 839 \\
\hline Learning & $16(10,6 \%)$ & $21(16,0 \%)$ & $135(89,4 \%)$ & $110(84,0 \%)$ &, 178 \\
\hline
\end{tabular}




\section{Attitudes connected with leisure time spending}

In addition to mapping leisure time habits, the survey also tested how much importance was given to the following factors: acquiring new skills $(45.6 \%)$, staying fit $(71.4 \%)$, trying new things $(58.3 \%)$, meeting new people $(54.4 \%)$, shopping / fashion $(36.7 \%)$, hobby $(60.1 \%) .48 .3 \%$ of the boys consider the " acquiring new skills " important while the majority of girls (49.6\%) opted for the "neutral" answer. On the other hand, the question of how important shopping and fashion was reversed the response rate as in the case of girls, $47.3 \%$ considered it important whereas $43 \%$ of boys rated it as neutral. The importance of health and fitness viewed as something positive for young people, boys $(73.5 \%)$ and girls (69.5\%). As for "hobby", "meeting new people" and "trying new things", the results show that they play a major role in leisure activities and it is also apparent that motivation is more prevalent among boys (see Table 2). In the study of leisure-time attitudes (acquiring new skills, fitness, new things, meeting new people, fashion, hobbies) responses showed significant differences by gender $(\mathrm{p}<0.05)$.

\section{Leisure-sport preferences}

Out of the recreational activities of young people, competitive sport was one of the least popular $(12.1 \%)$. Competitive athletes are those who have sports club membership and have trainings at least two to three times a week out of school. If we look at the proportion of extracurricular leisure-time sports among students, it is as follows: $58,3 \%$ of the boys are involved in extracurricular leisuresport activities while for the girls it is 53,8\%. 57,8\% of boys do sport regularly in their leisure time (once a week, 2-3 times a week, daily) while for the girls it is only $50,4 \%$. In summary it can be stated that over half of the students do not do sport competitively, however, they do sport regularly on the hobby level, the main motivations being the good company, fun and relaxation (figure 5).

Table 2.: Leisure time spending attitudes of respondents by gender (Source: Authors' editing)

\begin{tabular}{|c|c|c|c|c|c|c|c|c|c|c|c|c|}
\hline \multirow{2}{*}{$\begin{array}{l}\text { Attitudes } \\
\text { connected to } \\
\text { leisure time } \\
\text { spending }\end{array}$} & \multicolumn{2}{|c|}{$\begin{array}{l}\text { Acquiring new } \\
\text { skills }\end{array}$} & \multicolumn{2}{|c|}{ Staying fit } & \multicolumn{2}{|c|}{$\begin{array}{l}\text { Trying new } \\
\text { things }\end{array}$} & \multicolumn{2}{|c|}{$\begin{array}{l}\text { Meeting new } \\
\text { people }\end{array}$} & \multicolumn{2}{|c|}{$\begin{array}{l}\text { Shopping/ } \\
\text { Fashion }\end{array}$} & \multicolumn{2}{|c|}{ Hobby } \\
\hline & $\begin{array}{c}\text { Boy } \\
\%\end{array}$ & $\begin{array}{c}\text { Girl } \\
\%\end{array}$ & $\begin{array}{c}\text { Boy } \\
\%\end{array}$ & $\begin{array}{c}\text { Girl } \\
\%\end{array}$ & $\begin{array}{c}\text { Boy } \\
\%\end{array}$ & $\begin{array}{c}\text { Girl } \\
\%\end{array}$ & $\begin{array}{c}\text { Boy } \\
\%\end{array}$ & $\begin{array}{c}\text { Girl } \\
\%\end{array}$ & $\begin{array}{c}\text { Boy } \\
\%\end{array}$ & $\begin{array}{c}\text { Girl } \\
\%\end{array}$ & $\begin{array}{c}\text { Boy } \\
\%\end{array}$ & $\begin{array}{c}\text { Girl } \\
\%\end{array}$ \\
\hline Important & 48,3 & 42,7 & 73,5 & 69,5 & 66,2 & 49,6 & 57,0 & 51,9 & 27,8 & 47,3 & 66,2 & 53,4 \\
\hline $\begin{array}{l}\text { Not im- } \\
\text { portant }\end{array}$ & 7,9 & 7,6 & 5,3 & 6,1 & 6,0 & 8,4 & 6,6 & 9,2 & 29,1 & 17,6 & 6,0 & 6,1 \\
\hline Neutral & 43,7 & 49,6 & 21,2 & 24,4 & 27,8 & 42,0 & 36,4 & 38,9 & 43,0 & 35,1 & 27,8 & 40,5 \\
\hline
\end{tabular}

Figure 5.: Proportions of extracurricular leisure-sport among respondents by gender (Source: Authors' editing)

\section{Proportions of extracurricular leisure-sport among respondents by gender}

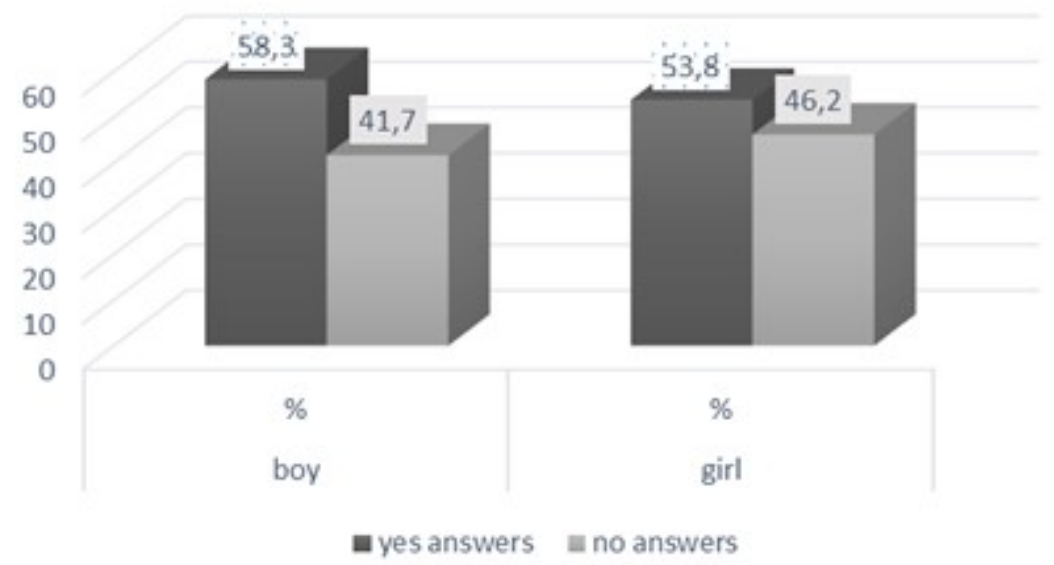


The importance of spending time with the family

The importance of leisure time spent with the family was examined through the following question: "How much do you consider it important to spend time with the family?" $76.3 \%$ of the respondents think that family time is important, of whom $80.9 \%$ are boys $72.8 \%$ are girls. For girls, leisure time sports with the family are more important than for boys. Thus, there is a significant difference $(\mathrm{Ch} 2=285.568, \mathrm{df}=6, \mathrm{p}=0.000)$ in the answers of the two sexes. In women, the family appears as a dominant value category. Szabó (2006) also found differences in the value orientation of normal young people: For women health, friendship, honesty, family, inner peace, while for men money and material goods are more important. Thus, Szabó (2006) also emphasized the importance of the family in the value preferences of women based on the results of his research.

\section{Discussion}

In the life of children with disabilities, recreational activities are of paramount importance as they can contribute to skills development, improving their health, helping the process of socialization and integration. Experience and skills developed during leisure activities can also help them in the learning process. In our survey, we found that passive options (reading, listening to music, watching TV) are predominant in the recreational activities of children with disabilities. In the case of leisure activities, for young people with disabilities, staying fit, trying out new things, and communal experience are the dominant motivating factors. Recreational sport proved to be popular as more than $50 \%$ of both girls and boys say they regularly do some kind of recreational sport.

\section{Limitations}

$26,7 \%$ of our respondents were mentally handicapped and in spite of the fact that they were assisted by teachers while completing the questionnaire it had to be taken into account when analysing the answers. Results were, thus, assessed in the awareness of this limitation.

\section{Conclusions}

Disabled students' leisure consumption is dominated by spending leisure passively, with listening to music and watching TV being the most frequent recreational activities. Based on secondary research this recreational consumption pattern of young people with disabilities was similar to that of normal youth. Our gender-based comparison con- firmed the tendency for girls to prefer listening to music and reading while boys showed higher interest in watching sport channels. For leisure activities, staying fit, trying out new things, and community experiences are essential for disabled students. Competitive sports are not the most popular leisure activities for young people with disabilities, but leisure sports were found to be popular as more than $50 \%$ of girls and boys say they do leisure sports. For disabled students, it is necessary to further promote leisure-sports and to expand the range of leisure sports opportunities offered to them. In marketing communication, fitness, health, new forms of movement and friendly communities can be the buzzwords for increasing their participation in leisure-sports. It can help maintain and improve their quality of life and health.

This publication was supported by EFOP-3.6.2-16-201700003 project. The project was accomplished with the support of the European Union and the co-financing by the European Social Fund.

\section{REFERENCES}

Alysha A, Walter MC, \& Bryan P. (2017): Aquatic activity and emotional experience in adults with severe mental illness. Am J Recreat Ther. 13.(3). 7-12. doi:10.5055/AJRT.2014.0074.

Balázs-Földi E., \& Dajnoki K. (2016): Sajátosságoke a fogyatékos és megváltozott munkaképességü munkavállalók foglalkoztatásában. 3.:(No.1). 313-318.

Bánhidi M. (2016): Rekreológia. Magyar Sporttudományi Társaság, Budapest.

Bedini, L. A. (2000): Just sit down so we can talk: Perceived stigma and the pursuit of community recreation for people with disabilities. Therapeutic Recreation Journal, 34. 55-68.

Block M. E., Taliaferro A., \& Moran T. (2013): Physical Activity and Youth with Disabilities: Barriers and Supports. Prevention Researcher 20, (18.).

Boda E., Honfi L., Bíró M., Révész L., \& Müller A. (2015): A szabadidő eltöltésének és a rekreációs tevékenységek vizsgálata egri lakosok körében. Acta Academiae Agriensis Nova Series Tom-Sectio Sport, 42. 49-62.

Borbély A., \& Müller A. (2008): A testi-lelki barmónia összefüggései és módszertana. Valóság-Térkép-6. Professzorok az Európai Magyarországért Egyesület, Budapest.

Borbély A., \& Müller A. (2015): Sport és Turizmus. Campus Kiadó, Debrecen.

Bota A., Teodorescu S., \& Serbanoiu S. (2014): Unified Sports - a Social Inclusion Factor in School Communities for Young People with In- 
tellectual Disabilities. 3rd International Congress on Physical Education, Sport and Kinetotherapy (Icpesk 2013) 117. 21-26.

Broach E., Dattilo J. (2003): The effect of aquatic therapy on strength of adults with multiple sclerosis. Ther Recreation J., 37(3). 224-239.

Bullock, C. C., \& Mahon, M. J. , Killingsworth, C. L. (2010): Introduction to recreation services for people with disabilities: a person-centered approach. USA.3

Coleman, D., \& Iso-Ahola, S. E. (1993). Leisure and health: The role of social support and selfdetermination. Journal of Leisure Research, 25. 111125.

Coyle, C., Kinney, W. B., Riley, B., \& Shank, J. W. (Eds.). (1991): Benefits of therapeutic recreation: $A$ consensus view. Philadelphia: Temple University.

Crocker, J., \& Major, B. (1989): Social stigma and self-esteem: The self-protective properties of stigma. Psychological Review, 96(4), 608-630.

Dattilo, J. (1994): Inclusive leisure services: Responding to the rights of people with disabilities. State College, PA: Venture.

Davis J., \& Nelson R. (2015): Aquatic exercise for pain management in older adults with osteoarthritis. Ther Recreation J. 49(4). 326.

Dobay B., Bánhidi M., \& Simonek J. (2018): Effects of outdoor education on traveling habits of adults in Slovakia and Hungary. Journal of Physical Education and Sport 18(2). 731-738.

Dobozy L., \& Jakabházy L. (1992): Sportrekreáció. Magyar Testnevelési Egyetem, Budapest.

Esélyegyenlőségi Törvény (1998): 1998. évi XXVI. Törvény a fogyatékos személyek jogairól és esélyegyenlőségük biztositásáról. I. fejezet Általános rendelkezések.

Fogyatékosügyi Program (1999): 100/1999 (XII. 10.) OGY határozat az Országos Fogyatékosügyi Programról Esélyegyenlőség megteremtéséhez szükséges intézkedések és feladatok a sport és szabadidő területén.

Funderburk J. A., \& Callis S. (2010): Aquatic intervention effect on quality of life prior to obesity surgery: A pilot study. Annu Ther Recreation, 18. 66-78.

Gaskell J., Janssen M. S. (2014): Benefits of a structure swim program for children diagnosed within the autism spectrum disorder. Am J Ther Recreation. 13(1). 9-16.

Gombás J. (2016): Budapesten élók 18-65 év közötti látássérült személyek szabadidó-sportolási szokásainak és szabadidósport látásséruiltek számára akadálymentes bozzáférésének vizsgálata. Doktori értekezés. Testnevelési Egyetem, Budapest.

Hidvégi P., \& Honfi L. (2008): Fogyatékos személyek rekreációja. Acta Academiae Paedagogicae Agriensis Nova Series: Sectio Sport, 35. 21-36.
Hodges, J., Luken, K., \& Zook, B. (2001): Recreational therapy can help adult brain injury survivors get back into the community. North Carolina Medical Journal. 62. 355-358.

Iwasaki, Y., Coyle, C. P., \& Shank, J. W. (2010): Leisure as a context for active living, recovery, health and life quality for persons with mental illness in a global context. Health promotion international, 25(4). 483-494.

Johnson C.C. (2009): The Benefits of Physical Activity for Youth with Developmental Disabilities: A Systematic Review. American Journal of Health Promotion, 23. 157-167.

Kissow A. M. (2015) Participation in physical activity and the everyday life of people with physical disabilities: a review of the literature. Scandinavian Journal of Disability Research, 17. 144-123.

Kovács T. A. (2003): A rekereáció elmélete és módszertana. Jegyzet Fitness Kft. Budapest.

KSH (2014): 2011. Évi Népszámlálás - 11. Fogyatékossággal élők. Központi Statisztikai Hivatal. Budapest.

Laoues N. (2017): A család és az oktatási intézmény szerepe a fogyatékkal éló gyermekek fejlődésében. In Vargáné Nagy Anikó (szerk.).: Családi nevelés 2. Didakt Kft., Debrecen. 19-49.

Lawson L., Foster L., \& Harrington M. (2014): Effects of a swim program for children with autism spectrum disorder on skills, interest, and participation in swimming. Am $J$ Recreation Ther.13(2). 17-27.

McCormick B.P., Snethen G., Smith R.L. (2012): Active leisure in the emotional experience of people with schizophrenia. Ther Recreation J. 46(3). 179-190.

Michalkó G. (2012): Research methods for leisure, recreation, and tourism. Annals Of Tourism Research, 39. (2). 1278-1279.

Móré M., Mező K. (2016): Fogyatékossággal élők a tanulástól a munkavállalásig. Különleges Bánásmód, 2. (1). 17-26. DOI 10.18458/KB.2016.1.17

Mosonyi A., Könyves E., Fodor I., \& Müller A. (2013): Leisure activities and travel habits of College students in the light of a survey. Apstract. Applied Studies in Agribusiness and Commerce, 7. (1). 57-61.

Murányi I. (2010): Egyetemisták szabadidős tevékenysége és mentális státusza. Educatio, 2. 203-213.

Müller A., Pfau C., Gabnai Z., Bácsné Bába É., Borbély A., \& Pető K. (2018): A gyógy-, wellness- és sportszolgáltatások fejlesztési lehetőségei a gyógyturizmusban egy hazai kutatás tükrében. International Journal of Engineering and Management Sciences/Müszaki és Menedzsment Tudományi Közlemények, 3. (4). 101-114. 
Müller A. (2009a): A legújabb trendek a sportmarketing és menedzsment területén. In Magyar Sporttudományi Társaság Sportinnovációs Szakbirottság Évkëonyve. 59-63.

Müller A. (2009b): $\quad$ A szabadidôs tevékenységek kinálati elemeinek vizsgálata az, egészségtudatos magatartás kialakitásában. (Debreceni Egyetem ATCAVK, szervezés és gazdálkodás tudományok területe) habilitáció.

Müller A., Bíró M., Bodolai M., Hidvégi P., Váczi P., Dávid L., \& Szántó Á. (2017): A 2016-os fitnesztrendek helye és szerepe a rekreációban. Acta Academiae Paedagogicae Agriensis Nova Series: Sectio Sport 44. 91-102.

Révész L., Müller A., Herpainé L. J., Boda E., \& Bíró M. (2015): A rekreáció elmélete és módszertana 1. A rekreáció kialakulása, története. A rekreáció felosztása. EKF, Líceum Kiadó, Eger.

Roberts, K., Lamb, K. L., Dench, S., \& Brodie, D. A. (1989): Leisure patterns, health status, and employment status. Leisure Studies, 8. 229-235.

Sáringerné Sz. Zs (2014): Fogyatékossággal élők sportolási lehetőségei. In Gál A., Dóczi T., \& Sáringerné Szilárd Zs: Társadalmi befogadás a sportban és a sport által (szociális inkluirió).

Shaw G., \& Coles T (2004): Disability, holiday making and the tourism industry in the UK: a preliminary survey. Tourism Management. 25.(3). $397-403$

Szabó Á. (2006): Egyetemisták szabadidôsport- (szolgáltatás) fogyasztásai. Műhelytanulmány. Corvinus Egyetem. Budapest.

WHO - World Bank (2011): World report on disability.

http://www.who.int/disabilities/world_report/ 2011/report.pdf Letöltés ideje: 2018.12.03. 